\title{
Defesa da mais famosa Górgona
}

\author{
Medusa Medusa \\ artista injustiçada \\ maior escultora da Antiguidade \\ grande representante da mimese \\ inventora da action sculpting \\ fiel aos princípios \\ da Teoria da Recepção \\ proponente da interação \\ com a plateia \\ muito antes do Teatro Oficina \\ praticante da arte democrática \\ acessível compreensível \\ a todos os substratos sociais \\ confiante nos próprios procedimentos \\ defensora da não-separação \\ entre forma e conteúdo \\ que forma e conteúdo ajustam-se \\ mutuamente \\ inseparáveis tua vida e obra \\ cuja beleza habita nos teus olhos \\ de observadora \\ da natureza humana \\ Medusa Medusa \\ diz a esta geração de Dorian Grays \\ a esta milícia dos frágeis \\ a esta congregação de doridas greis \\ que a lealdade à própria manufatura \\ à própria oftalmofatura \\ ainda que nos custe as serpentes \\ e os cabelos
}




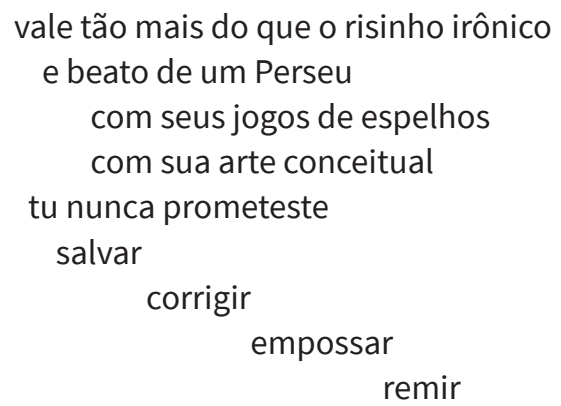

jamais te incumbiste a ti mesma

de salvar princesas

Medusa Medusa

nós seguidores anacrônicos

de tua escola artística

do teu lúcido -ismo sem manifesto

nós que não somos

nem bons nem moços

nós teus discípulos

exegetas do exagero

sempre com o dedo no gatilho

sabemos

que o rugoso o áspero o sibilante

o desagradável o bruto

são também joia e quitute

teus filhos destemidos e feios

que estragam o jantar alheio

com as cinzas do cinza

negligentes do bem-estar social

sabemos que jamais temeste

o espelho

ou o reflexo e a reflexão-de-si

mas o aguardaste paciente

para consumar tua intrínseca vidobra 
NOTA

* Ricardo Domeneck [@ricardoxdomeneck] é um poeta, contista e ensaísta brasileiro, nascido em Bebedouro, São Paulo, em 1977. Lançou as coletâneas de poemas Carta aos anfíbios (Bem-Te-Vi, 2005), a cadela sem Logos (Cosac Naify/7Letras, 2007), Sons: Arranjo: Garganta (Cosac Naify/7Letras, 2009), Cigarros na cama (Berinjela, 2011), Ciclo do amante substituível (7Letras, 2012), Medir com as próprias mãos a febre (7Letras, 2015), Odes a Maximin (Garupa, 2018) e O Morse desse corpo (7letras, 2020). Em prosa, lançou Manual para melodrama (7Letras, 2016) e Sob a sombra da aboboreira (7Letras, 2017). Foi coeditor das revistas Modo de Usar \& Co. (2007-2017) e Cabaret Wittgenstein, assim como colunista da Deutsche Welle Brasil. 